\title{
PERANCANGAN SISTEM INFORMASI PENDISTRIBUSIAN (STUDI KASUS PADA DI PT.TRIMITRA ARGA MULIA CILEGON)
}

\author{
Syaechurodji ${ }^{1}$, Rizki Fatullah ${ }^{2}$ \\ Universitas Banten Jaya \\ Jl. Syeh Nawawi Al-Bantani, Boru, Curug, Serang - Banten, Indonesia \\ Email: syaechurodji@unbaja.ac.id', rizkifath@unbaja.ac.id ${ }^{2}$
}

\begin{abstract}
PT. Trimitra Arga Mulia is one of the companies engaged in the Distribution of Drinking Water, where drinking water is really needed by all people, especially in urban areas. The purpose of writing this report is to find out how the system used by the company is there many obstacles or not. The method used by the author is by direct observation to the field, question and answer with employees and leaders, and look for books related to distribution. After conducting observations on the company, the authors found weaknesses such as when employees make deliveries to each route with drivers that have been determined, then stock gallons in warehouses and data collection of new and outgoing customers, and data processing, causing data inaccuracies. These weaknesses are determined because the system is still semi computerized. From the results of research conducted by the author, it is concluded that it is necessary to hold an improved system that has been integrated with the database in processing data and in making reports.
\end{abstract}

Keywords: Design, Information System, Distribution

\section{PENDAHULUAN}

Pendistribusian merupakan bagian pekerjaan di perusahaan yang sangat penting. Pengelolaan air dalam pendistribusian harus benar dan tepat agar dapat memberikan pelayanan kepada para pelanggan yang efektif dan tepat waktu. Pendistribusian sangat dibutuhkan dalam pelaksanaan pengelolaan perusahaan air minum karena pendistribusian merupakan tolak ukur untuk mencapai target perusahaan. Tanpa pendistribusian tidak mungkin sebuah perusahaan air minum ini dapat mencapai target yang maksimal. Oleh karena itu suatu perusahaan dalam mengelola pendistribusian harus memperhatikan sistem pendistribusian yang sesuai dengan keadaan perusahaan dalam mencapai tujuan. Efektifitas pengelolaan pendistribusian pada perusahaan dipengaruhi pula oleh pegawai yang 
bekerja pada unit pendistribusian dan petugas pengiriman, sarana atau fasilitas yang dipengaruhi dalam membantu pengelolaan pendistribusian.

Fungsi pendistribusian sebagai tolak ukur suatu perusahaan air minum dalam penyediaan produk air minum dan pengaturan pengiriman kepada konsumen serta pendataan stok di gudang sesuai dengan jumlah yg akan di kirim ke konsumen. Dalam hal ini unit pendistribusian harus senantiasa siap untuk memberikan pelayanan kepada pelanggan yang lebih baik dan tepat waktu. Untuk dapat mengemban tugas seperti ini, pegawai yang bekerja pada unit pendistribusian bukan hanya ditunjang oleh faktor kemauan terhadap pekerjaannya, melainkan juga harus dibekali keterampilan mengenai bidang pendistribusian.

Berdasarkan uraian di atas peneliti mengidentifikasi masalah-masalah di dalam perusahaan tersebut diantaranya:

1. Sistem pengiriman air minum mineral di PT.Trimitra Arga Mulia kepada konsumen tidak tepat waktu.

2. Sistem pendistribusian air minum mineral tidak dapat mengelola dengan baik penyediaan air minum di gudang PT.Trimitra Arga Mulia

3. Sistem pendataan pelanggan baru dan pelanggan keluar tidak terkordinir dengan baik

\section{METODE}

Metode yang digunakan dalam penelitian ini menggunakan Rapid Aplication Development (RAD) adalah proses pengembangan perangkat lunak yang bersifat inkremental terutama untuk waktu pengerjaan yang pendek (A.S Rosa dan M. Shalahudin,2013). Berikut adalah gambaran dan penjelasan dari model RAD. 


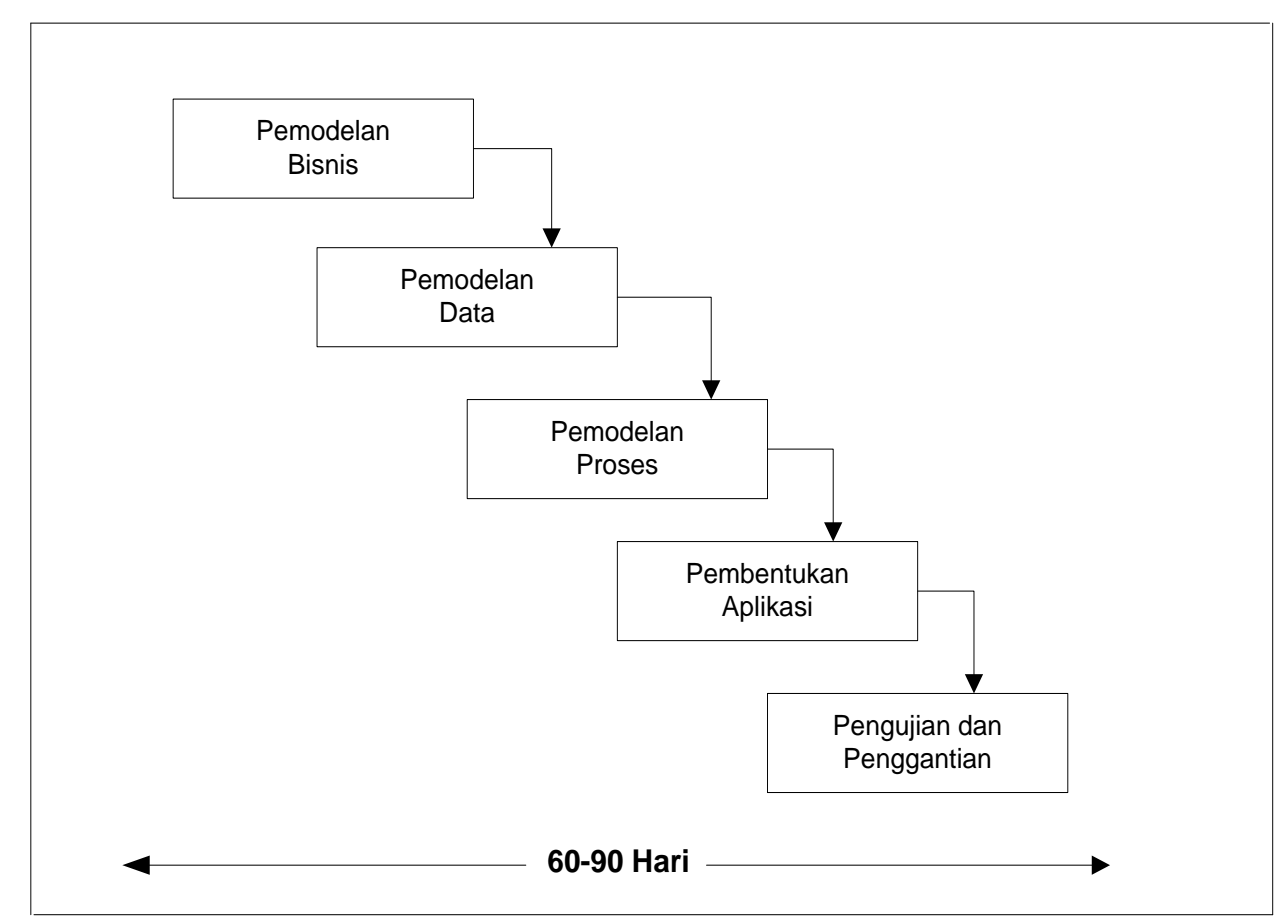

\section{Gambar 1. Model RAD}

\section{Tahapan-tahapan dalam RAD:}

a. Pemodelan Bisnis

Tahap ini untuk mencari aliran informasi yang dapat menjawab pertanyaan berikut: Informasi apa yang mengendalikan proses bisnis? Informasi apa yang dimunculkan? Di mana informasi digunakan? Siapa yang memprosesnya?

b. Pemodelan Data

Menjelaskan objek data yang dibutuhkan dalam proyek. Karakteristik (atribut) masing-masing data diidentifikasikan dan hubungan antara objek didefinisikan.

c. Pemodelan Proses

Aliran informasi pada tahap data modeling ditransformasikan untuk mendapatkan aliran informasi yang diperlukan pada implementasi fungsi bisnis. Pemrosesan diciptakan untuk menambah, memodifikasi, menghapus, atu mendapatkan kembali objek data tertentu.

d. Pembentukan Aplikasi

Selain menggunakan bahasa pemrograman generasi ketiga, RAD juga memakai komponen program yang telah ada atau menciptakan komponen yang 
bisa dipakai lagi. Alat-alat bantu bisa dipakai untuk memfasilitasi konstruksi perangkat lunak.

e. Pengujian dan Penggantian

Karena menggunakan kembali komponen yang telah ada, maka akan mengurangi waktu pengujian. Tetapi komponen baru harus diuji dan semua interface harus dilatih secara penuh.

\section{Kelebihan dan Kelemahan RAD}

a. Kelebihan :

1) Setiap fungsi mayor dapat dimodulkan dalam waktu tertentu kurang dari 3 bulan dan dapat dibicarakan oleh tim RAD yang terpisah dan kemudian diintegrasikan sehingga waktunya lebih efesien.

2) RAD mengikuti tahapan pengembangan sistem seperti umumnya, tetapi mempunyai kemampuan untuk menggunakan kembali komponen yang ada (reusable object) sehingga pengembang pengembang tidak perlu membuat dari awal lagi dan waktu lebih singkat.

b. Kelemahan :

1) Pada proyek yang besar dan berskala, RAD memerlukan sumer daya manusia yang memadai untuk menciptakan jumlah tim yang baik.

2) RAD menuntut pengembang dan pelanggan memiliki komitmen dalam aktivitas rapid fire yang diperlukan untuk melengkapi sebuah sistem dalam waktu yang singkat. Jika komitmen tersebut tidak ada maka proyek RAD akan gagal.

3) Tidak semua aplikasi sesuai untuk RAD. Biala sistem tidak dapat dimodulkan dengan teratur, pembangunan komponen penting RAD akan menjadi sangat bermasalah.

Rapid Aplication Development (RAD) adalah sebuah model proses perkemkangan perangkat lunak sekuensial linier yang menekankan siklus perkembangan yang sangat pendek. Model RAD ini merupakan sebuah adaptasi kecepatan tinggi dari model sekuensial linier dimana perkembangan cepat dicapai dengan menggunakan pendekatan kontruksi berbasis komponen. Proses RAD 
memungkinkan tim pengembang menciptakan sistem fungsional yang utuh dalam periode waktu yang sangat pendek (kira-kira 60 sampai 90 hari). (Roger S. Pressman, 2012)

\section{HASIL DAN PEMBAHASAN}

Berdasarkan rancangan sistem dan database yang penulis buat, maka penulis membuat program berdasarkan data-data yang diterima selama penelitian dan tidak mengalami hambatan-hambatan selama pelaksanaan uji coba ini penulis mendapat kemudahan didalam proses uji coba, berdasarkan hasil uji coba yang dilaksanakan hasilnya sesuai dengan yang diharapkan.

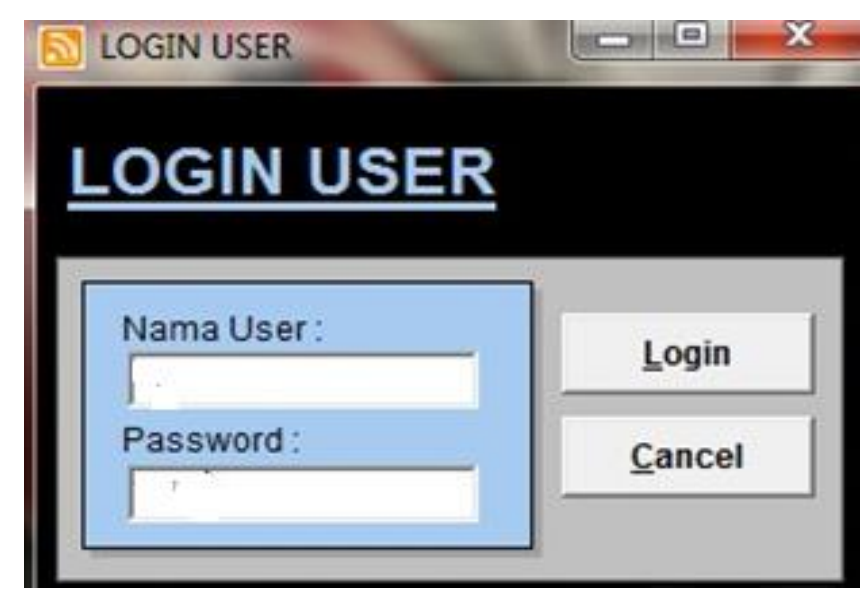

Gambar 2. Menu Login

Klik dua kali pada dekstop sorcat aquos, maka akan muncul login user yg terlihat pada gambar, setelah itu masukan nama user pada login dan masukan pasword nya. Setelah itu program siap dijalankan. 


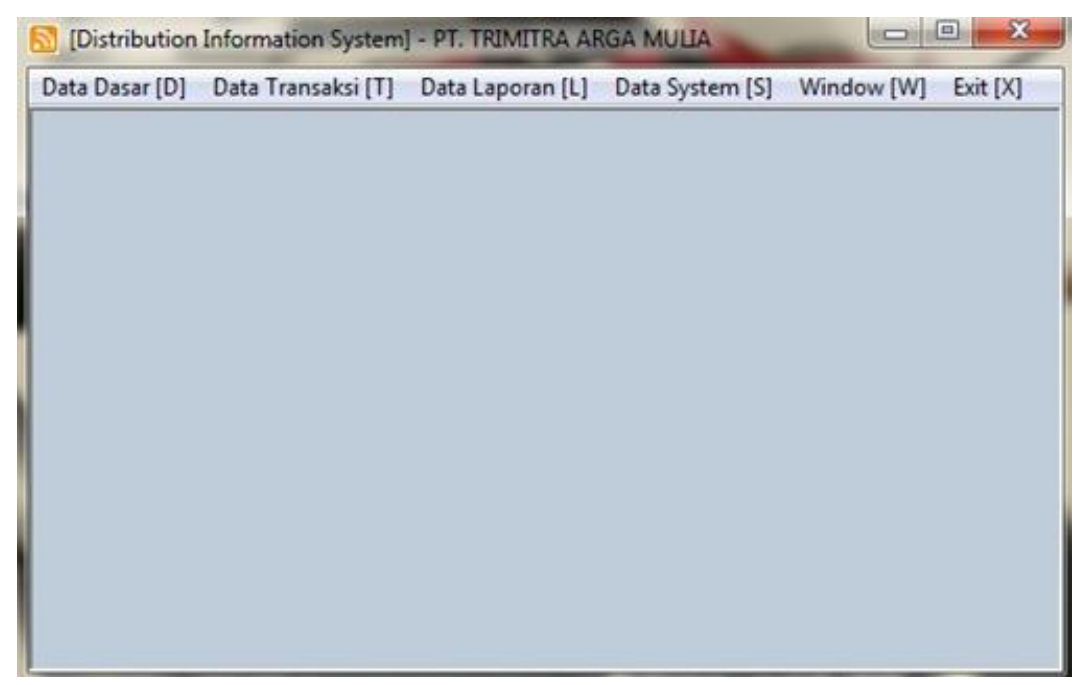

Gambar 3. Menu Utama

Setelah login user benar maka login akan muncul menu Data dasar, data transaksi, data laporan, data system dan terakhir exit. seperti gambar 3. Klik data dasar yang ada pada menu maka akan muncul Data Pelanggan, data supplier dan data barang, selain itu setiap tampilan ada icon tambah berfungsi untuk menambahkan item, hapus untuk menghapus item atau di batalkan, edit untuk merubah item yg terjadi kesalahan, simpan untuk menyimpan item yg sudah dibuat, batal untuk membatalkan item yg di buat, exit yaitu keluar dari direktori. Data pelanggan yaitu data dimana setiap pelanggan yang baru atau lama terdata di sini.

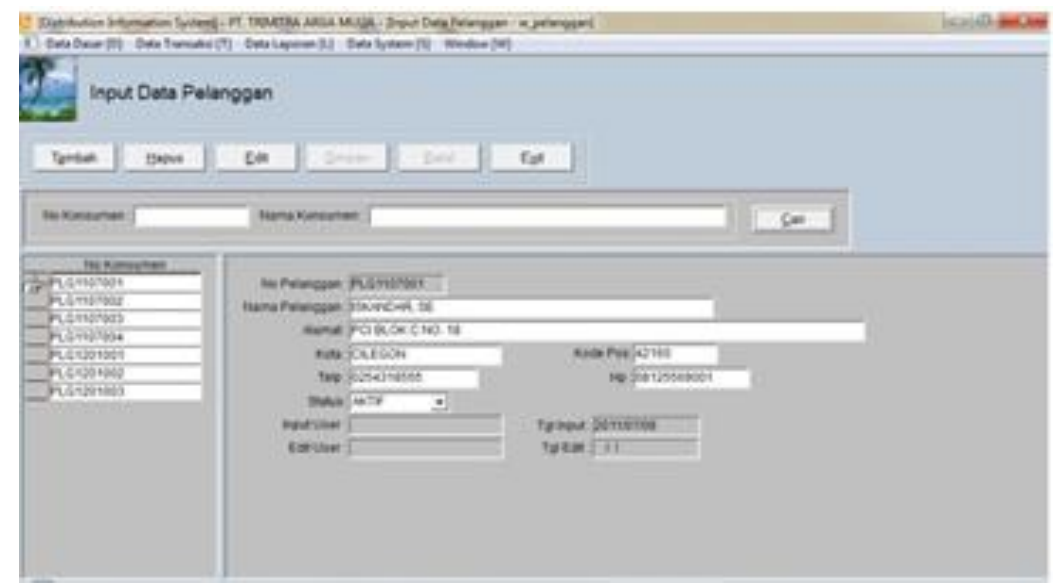

Gambar 4 Input Data Pelanggan 
Data Supplier adalah data yang memuat supplier kepada perusahaan pada saat perusahaan meminta SP kepada Supplier kemudian di input ke data supplier.

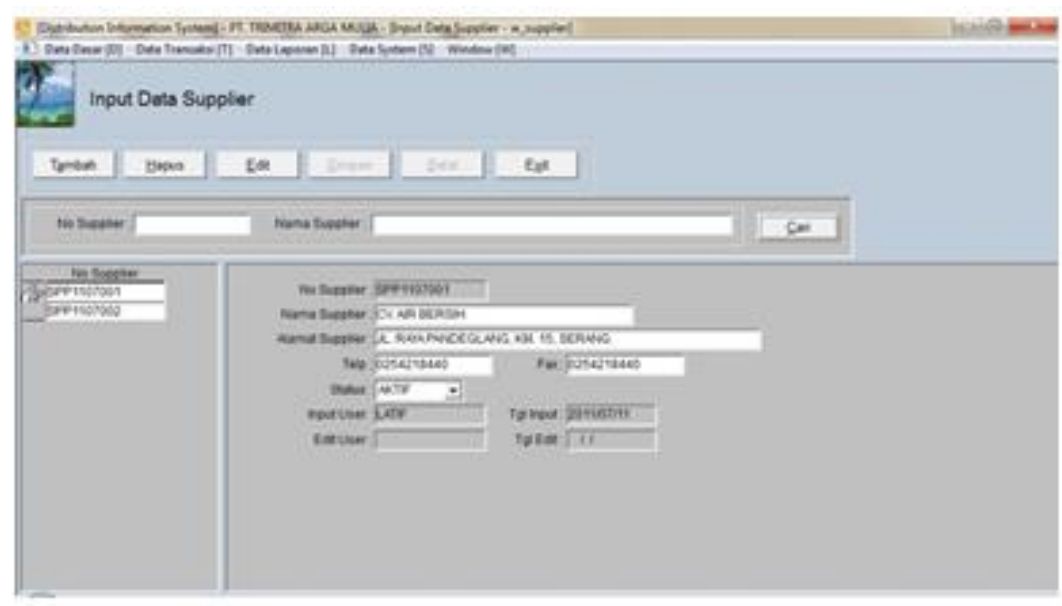

\section{Gambar 5. Input Data Supplier}

Input data barang adalah setiap SP barang setiap kali transaksi kemudian ter input ke data barang.

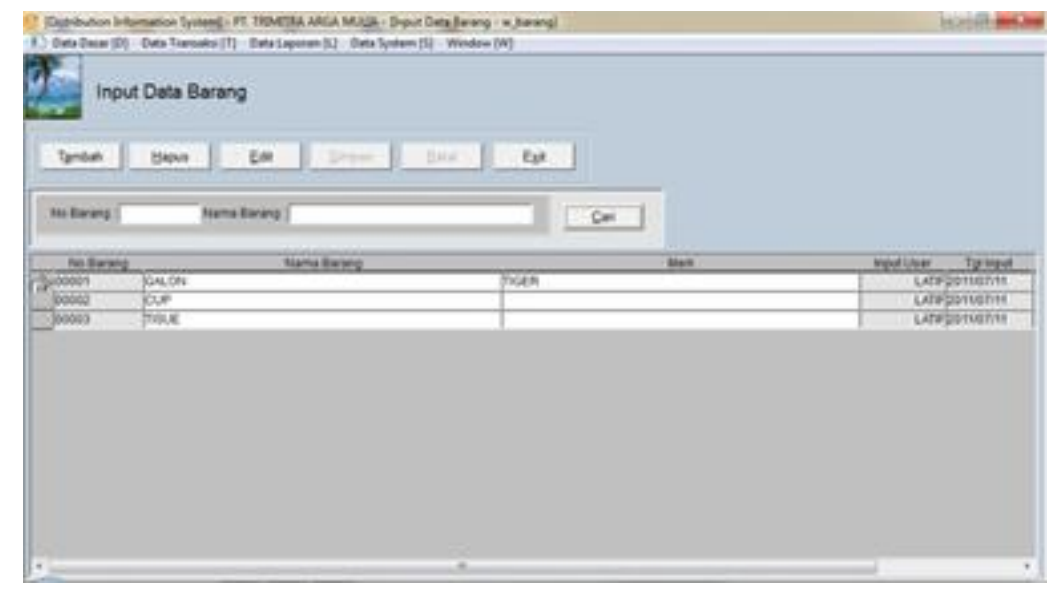

Gambar 6. Input Data Barang

Data SP adalah data dimana setiap permintaan pelanggan dengan qty trtntu di input kedalam input data SP. 


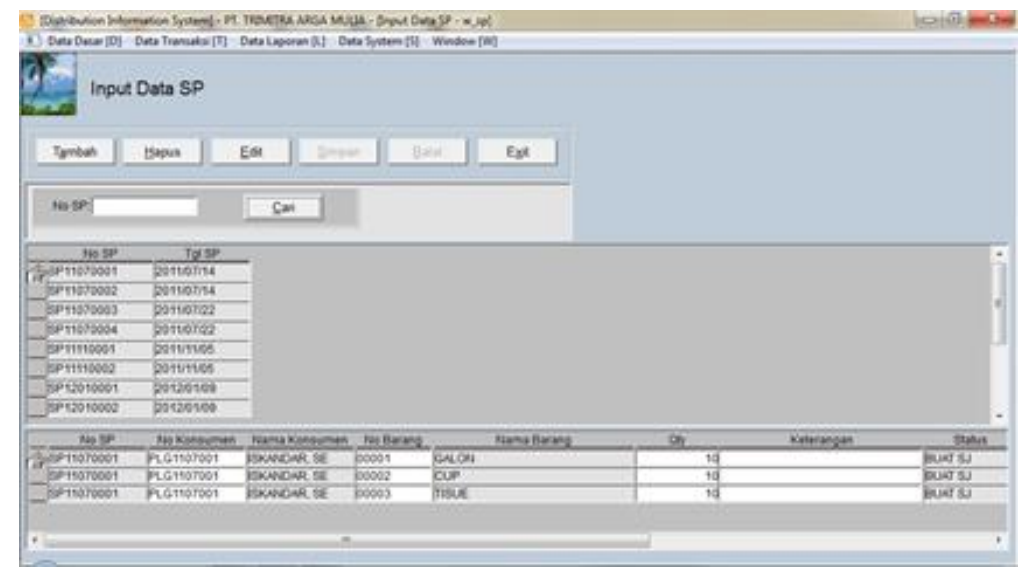

Gambar 7. Input Data SP

Buat order yaitu pada saat pengiriman kepada pelangganmaka akan dibuatkan SP setelah itu akan dibuat order.

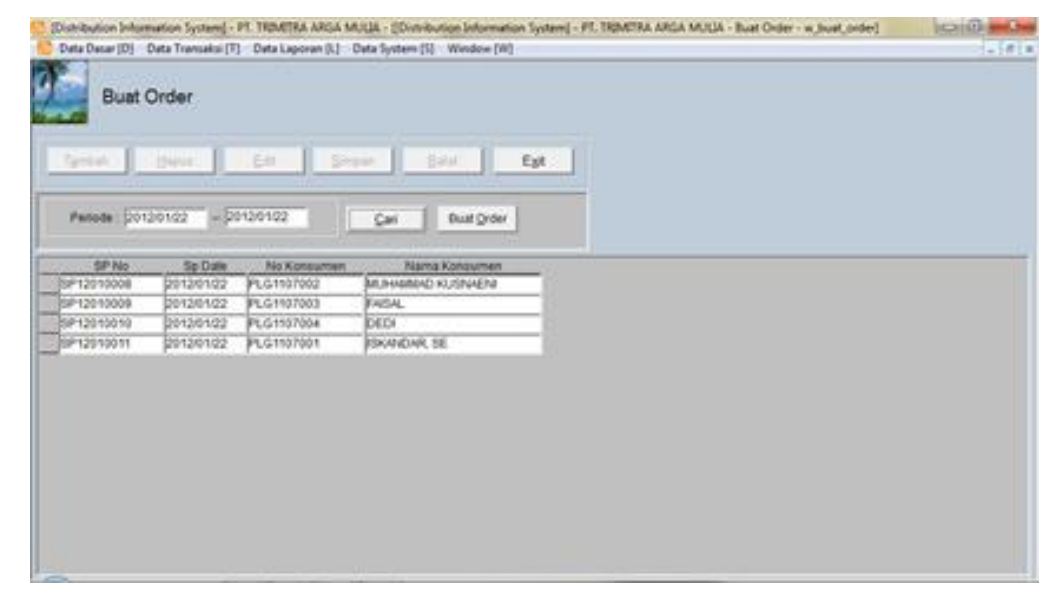

Gambar 8. Buat Order

Data order yaitu setiap data SP akan terdata dan masuk ke dalam data order. 


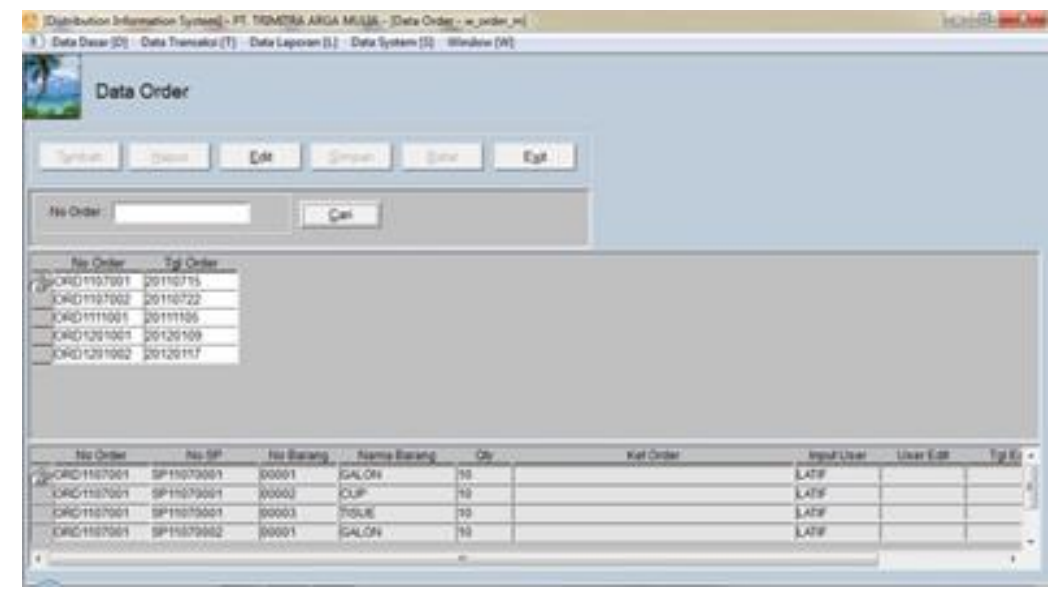

Gambar 9. Data Order

Input data ST yaitu pada saat supplier mengirimkan SP maka terdapat ST kemudian terinput ke dalam data ST

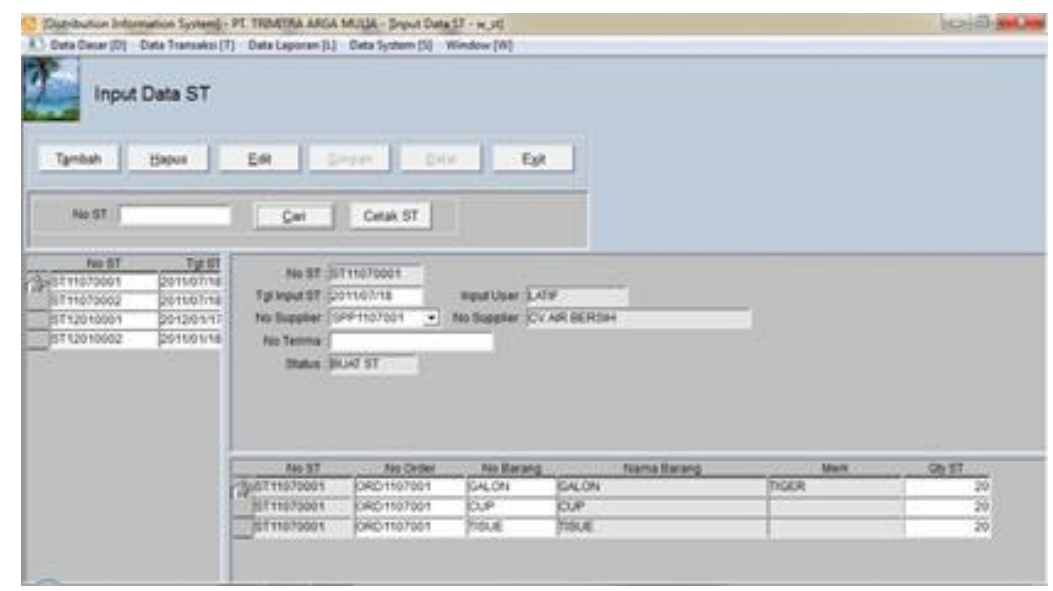

Gambar 10. Input Data SP

Input SJ yaitu pada saat menerima SP kemudian mendaatkan SP maka akan dibuatkan SJ yang akan terinput ke dalam SJ. 


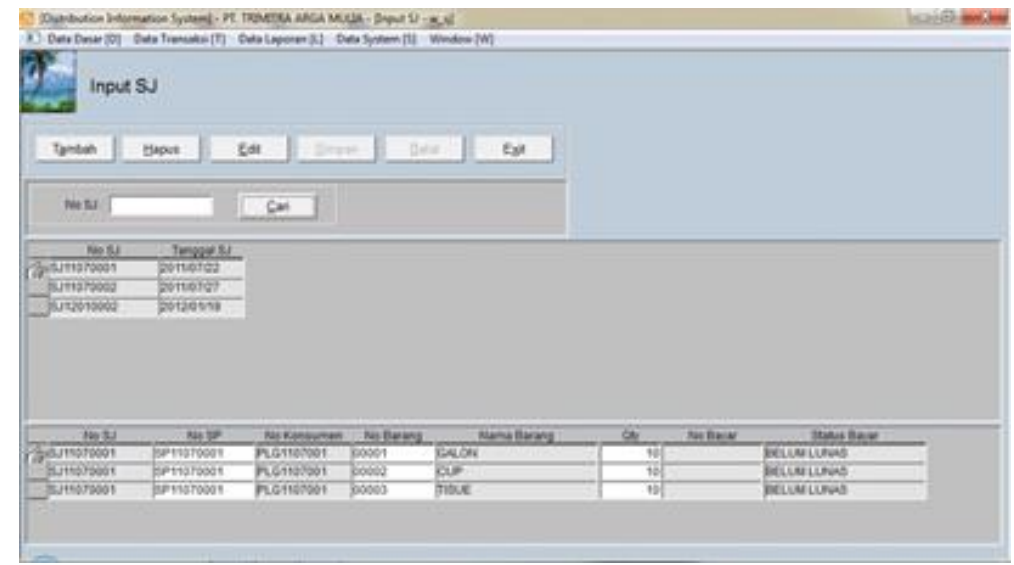

Gambar 11. Input SJ

Input data bayar yaitu setiap pelanngan yang mengambil SP maka akan menerima Sj kemudian akan terinput ke data bayar.

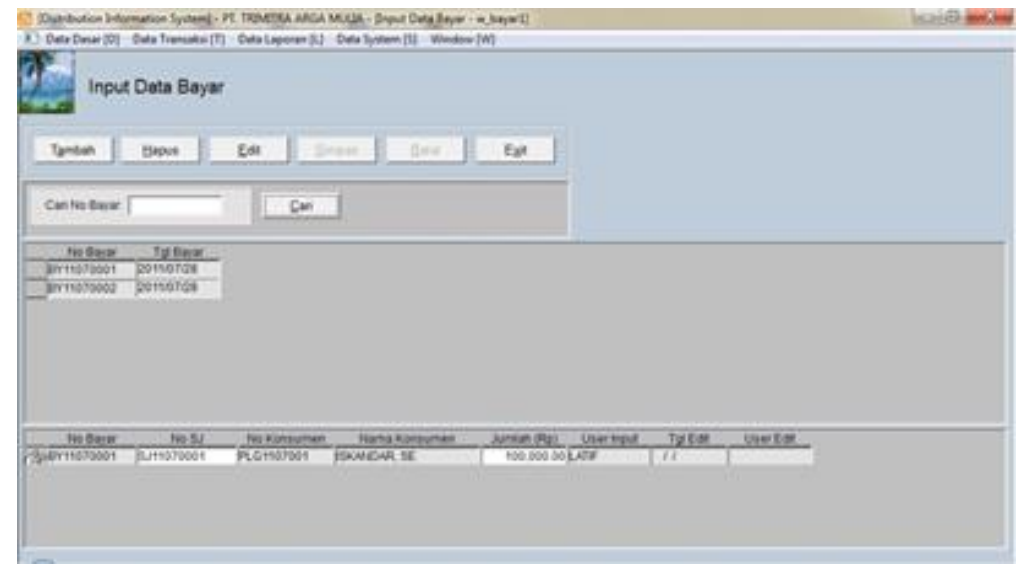

Gambar 12 Input Data Bayar

View Stock yaitu pada saat SP bertambah maka bisa di cek apakah stok d gudang masih bisa memberikan SP kepada pelannggan. Jika stock kurang maka akan d berikan SP kepada supplier 


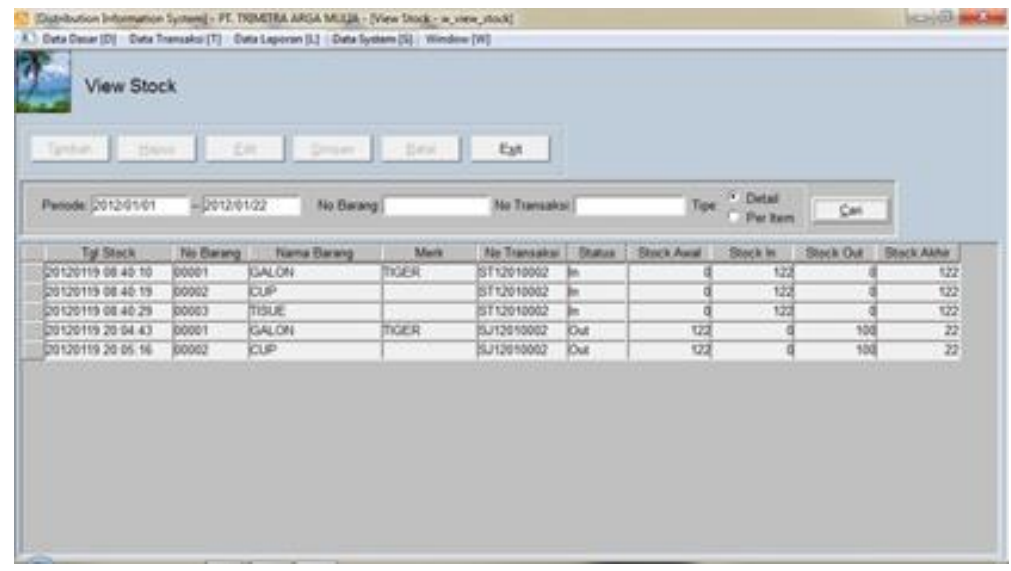

Gambar 13. View Stock

Laporan pelanggan yaitu data pelanggan yang masih aktif ataupun tidak aktif terdata pada laporan yg terinput pada data pelanggan

\section{KESIMPULAN}

Setelah penulis menganalisa, merumuskan dan merancang sistem usulan, maka penulis menarik kesimpulan bahwa sistem yang dibuat menjawab permasalahan diantaranya :

1. Kemasan barang yang dipakai bocor atau retak tidak dapat dipakai lagi dan teridentifikasi menjadi kemasan rusak.

2. Kemasan yang kadaluarsa dapat disajikan dalam laporan kemasan rusak.

3. Penyajian laporan bisa disajikan berdasarkan kriteria tertentu.

4. Kemasan yang terkirim dapat diketahui urutan pengirimannya.

\section{DAFTAR PUSTAKA}

Andri Kristanto,2012, Perancangan Sistem Informasi dan Aplikasinya, Gava Media, Yogyakarta

Amsyah, Zulkifli. 2010. Manajemen Sistem Informasi. Gramedia Pustaka Utama. Jakarta.

Aji Supriyanto. 2011. Pengantar Teknologi Informasi. Salemba Infotek. Jakarta

Al-Bahra bin Ladjamudin. 2009. Analisis dan Desain Sistem Informasi. Yogyakarta : Graha Ilmu.

Jogiyanto.HM, (2009), Konsep Sistem Informasi, Yogyakarta : Andi Publisher. 
Jurnal SIMIKA Vol. 2 No. 2 Tahun 2019

Siagian, Sondang P, 2010, Kiat Meningkatkan Produktivitas Kerja, Rineka Cipta, Jakarta

Suhata. 2010. VB Sebagai Pusat Kendali Peralatan Elektronik. Jakarta: PT. Elex. Media Komputindo 